\title{
How Mindfulness and Servant Leadership Affect Customer-Oriented Organizational Citizenship Behavior: Service Climate as Potential Mediator
}

\author{
Dhevy Puswiartika, Zahrotur Rusyda Hinduan, Marina Sulastiana, Diana Harding
}

\begin{abstract}
One aspect of competitive advantage that is now the main focus of the company is human resources. To improve the performance of organizations related to service excellence, it takes work behavior that exceeds the demands of work, namely Customer Oriented-Organizational Citizenship Behavior. This article is Proposal for Doctoral Colloquia that aims to prove the variables that influence Customer Oriented-Organizational Citizenship Behavior and obtain a model of the structural relationship between Mindfulness, Servant Leadership, Service Climate, and Customer Oriented-Organizational Citizenship Behavior. This study is explanatory survey research with a mixed-method approach. The participants of this study are the supervisor of railway transportation provider in Jakarta, Indonesia. The sampling technique is multistage sampling (a combination of cluster sampling and stratified sampling). The data will be collected by self-report surveys. The data will be analyzed by using Structural Equation Modelling with Lisrel 8.7 software. The results from this study will be proved and built a structural model of the effect of mindfulness and servant leadership on Customer Oriented-Organizational Citizenship Behavior through a service climate. The novelty of this study is the addition of contextual factors such as service climate as a mediator variable in testing the effect of mindfulness on workplace outcomes such as Customer Oriented-Organizational Citizenship Behavior and the influence of servant leadership on Customer Oriented-Organizational Citizenship Behavior, and the development of dispositional mindfulness instrument for Indonesian employees.
\end{abstract}

Keywords: Mindfulness; Servant Leadership; Service Climate; Customer Oriented-Organizational Citizenship Behavior; Railway Transportation Service Provider in Indonesia.

\section{INTRODUCTION}

In order to face the era of the ASEAN Economic Community, PT X, as a State-Owned Enterprise which runs railway service in Indonesia, had been changed the management in 2009-2014 which drastically changed and improved a lot of company's aspects and business practice. Specifically related to service improvement, there was a change in company orientation, from product-oriented to

Revised Manuscript Received on September 22, 2019

Dhevy Puswiartika, Doctoral Program of Psychology, Faculty of Psychology, Universitas Padjadjaran. dhevy16001@mail.unpad.com

Zahrotur Rusyda Hinduan, Doctoral Program of Psychology, Faculty of Psychology, Universitas Padjadjaran,

Marina Sulastiana, Doctoral Program of Psychology, Faculty of Psychology, Universitas Padjadjaran.

Diana Harding, Doctoral Program of Psychology, Faculty of Psychology, Universitas Padjadjaran customer-oriented. $\mathrm{PT} X$ has given excellent service as a company culture. PT $\mathrm{X}$ is also facing tough competition in providing transportation service industry in Indonesia. Transportation service industry belongs to the one with low switching cost. It means that its customers can suddenly switch to other transportation service providers when they are not satisfied with the service. This condition consequently requires PT X to create competitive advantages so that it has added values compared to the competitors.

One of the competitive advantages which becomes the company major focus is human resources. Every company should be able to see the existing challenges and potential in its human resources ${ }^{(1)}$. This high standard requires role behavior beyond ordinary profile. This kind of behavior is labeled as Organizational Citizenship Behavior or $\mathrm{OCB}^{(2)}$. Concerning this research on transportation service field, OCB which is oriented to and focused on customers will be stronger in determining service quality. An extra employee's behavior in offering service internally and externally, beyond the formal task system was called an OCB that oriented to the customer or Customer Oriented-Organizational Citizenship Behavior or CO-OCB (3) that inlined with one of the company cultures of PT X as a railway transportation service provider, that is excellent service. A specific OCB suited better to the staff who play roles in offering service to customers and representing the organization to external parties ${ }^{(4)}$.

It is important for the organization to recognize factors which improves $\mathrm{CO}-\mathrm{OCB}$ when it means to promote CO-OCB to its staff and workers ${ }^{(5)}$. The first factor was one's individual characteristics, those are personality, awareness, capability, knowledge, motives, and one's values. The second factor was working attitude, which are: organizational commitment, perception, leadership, and organization support, person-organization fit, job satisfaction, psychological contract, and justice perception. The third factor was then contextual factors, those were: organization climate, service climate, task characteristics, organization culture, and social role expectation.

Referring to the dominant factors in influencing CO-OCB based on the results of the preliminary study that conducted by the authors, this study will focus on individual characteristics (mindfulness), work attitudes (servant leadership), and contextual (service climate) factors as perceived by PT X supervisors. 
Regarding the differences or the individual characteristics, mindfulness is one of the right resources for supervisors who often face stressful situations, job challenges and a negative work climate ${ }^{(6)}$. A theoretical framework regarding mindfulness suggested that mindfulness can improve work performance ${ }^{(7,8)}$. Mindfulness was positively related to the dimensions of performance, namely: task performance and organizational citizenship behavior (OCB), and negatively related to the negative form of performance, namely: deviance $^{(9)}$. Organizational citizenship behaviors as one of job performance kinds were influenced by mindfulness, as one of the individual's personalities ${ }^{(9,10)}$. The studies on mindfulness at the workplace did not involve measuring the common individual differences and organizational context that can be a moderator or mediator in the relationship between mindfulness and workplace outcomes ${ }^{(8,11)}$.

Furthermore, work attitude factors that can influence the increase of CO-OCB are leadership. To be able to provide maximum service to internal and external customers, supervisors need to apply leadership that is consistent with the characteristics of the service, namely servant leadership. The previous studies specifically revealed that servant leadership was one of the factors that influence $\mathrm{OCB}{ }^{(3,12)}$. The contextual factor that can influence CO-OCB was the service climate. The conducive and comfortable climate was important to support the employees in performing their task that will lead them to the improvement of service commitment or $\mathrm{CO}-\mathrm{OCB}^{(13)}$.

Based on the description of the factors that influence the emergence of CO-OCB above, it can be concluded that the extra behavior of supervisors as citizens of the organization in providing customer-oriented services (CO-OCB) can be seen as output behavior that is also influenced by factors exist in the supervisor and organizational factors as the context of the environment. The main problem in this study is: "How does the effect of mindfulness and servant leadership on CO-OCB on PT X supervisors through service climate?"

\section{LITERATURE REVIEW}

Mindfulness defined as a characteristic or tendency for individuals to consciously focus attention on internal conditions in themselves and the environment outside themselves in their present experience here; accept every thought, feeling, or sensation that arises, without the need to elaborate and without giving judgment ${ }^{(14,15)}$. The results of the following studies showed that mindfulness was significantly associated with workplace outcomes, including: job performance outcomes, including: task performance, organizational citizenship behavior, and deviance ${ }^{(8-10)}$; relationship outcomes, including: empathy, servant leadership, work engagement, supervisory relationship, job satisfaction ${ }^{(16)}$, and well-being outcomes of employees $^{(13)}$.

Servant leadership focused on increasing service to others rather than to oneself ${ }^{(17)}$. Six characteristics specifically explain servant leadership behavior in a model of servant leadership, including empowering and developing people, humility, authenticity, interpersonal acceptance, providing direction, and stewardship ${ }^{(18)}$. Many studies had revealed that servant leadership had an influence on $\mathrm{OCB}^{(3,12,19-21)}$. The supervisor's support also influenced $\mathrm{OCB}^{(22)}$. Servant leadership was one of the factors that had a big impact on performance $^{(23)}$.

Service climate defined as the shared employee perceptions of the policy, practices, and the behaviors that get rewarded, supported, and expected concerning customer service and customer service quality ${ }^{(24)}$. There were 2 dimensions forming the service climate, including internal service, namely: Quality of service received by employees and managers of the organization to enable them to carry out their work; and Climate for Work Facilitation. In addition to these two dimensions of foundation, there were three other dimensions of service climate that play a role, namely: Customer Orientation, Managerial Practices, and Customer Feedback $^{(25)}$. The future research agenda of service climate included further specification of the framework's variables and linkages about the relative roles of individual and contextual attributes in creating service climate ${ }^{(26)}$. The conducive and comfortable climate was important to support the employees in performing their task that will lead them to the improvement of service commitment or $\mathrm{CO}-\mathrm{OCB}^{(13)}$. Service climate in partially had a role as mediator in the relationship between servant leadership and organizational citizenship behavior ${ }^{(27)}$. Service climate also fully mediated the relationship between CEO servant leadership and firm performance ${ }^{(28)}$.

An extra employee's behavior in offering service internally and externally, beyond the formal task system is called an OCB which is oriented to the customer or Customer Oriented-Organizational Citizenship Behavior or $\mathrm{CO}-O C B^{(3)}$. The dimensions of Customer-Oriented Organizational Citizenship Behavior (CO OCB), as follows: Helping behavior, Sportsmanship, Organizational Loyalty, Organizational Compliance, Individual Initiative, Civic Virtue, and Self Development ${ }^{(5)}$. In facing tough competition in the global era, high OCB is needed, as it is confirmed to lead to service quality improvement, making the interaction with customers be more convenient, and offering innovative ideas in advancing the service that leads to customer's satisfaction $^{(4,29,30)}$.

Fig 1. Conceptual Model

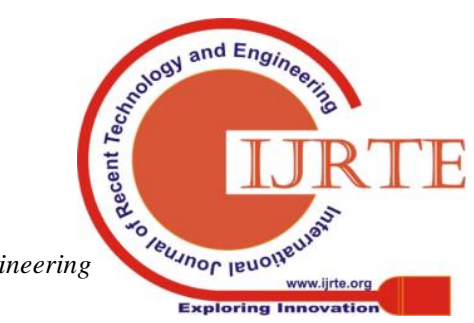




\section{Methodology}

\section{A. Research Approach}

This is mixed-method research which tries to combine quantitative and qualitative method, by combine exploration and understanding about individual or group as the sources of the problem and to test the theory with test the relationship between variables $^{(31)}$.

\section{B. Participants}

The participants of the study are the supervisors of the railway transportation service provider in the Jakarta area. The sampling is taken by using a multistage sampling technique, that combined cluster sampling dan stratified sampling. The target population in this study are 455 supervisors of PT X of Jakarta area, classified into two main groups of work, namely: operational and non-operational and spread in 18 job groups, and divided into 3 supervisory level positions, namely: Junior Supervisor, Supervisor, and Senior Supervisor.

\section{Instruments}

Considering the limitations of the currently available Indonesian version inventories measuring dispositional mindfulness which specifically to employees, the present study tried to take up the challenge and develop a Dispositional Mindfulness at Work Scale. Mindfulness is measured by using Dispositional Mindfulness at Work Scale which is developed by authors based on the mindfulness concept $^{(15)}$. Servant leadership is measured by using the Servant Leadership Scale which is developed based on servant leadership characteristics ${ }^{(32)}$. Service climate is measured by using Service Climate Scale which is developed based on the service climate concept ${ }^{(24)}$. Customer Oriented-Organizational Citizenship Behavior (CO-OCB) is measured by CO-OCB Scale which is developed by referring to the dimensions of Organizational Citizenship Behavior ${ }^{(5)}$.

\section{Data Analysis}

The qualitative data gained from Focus Group Discussion (FGD) are analyzed by using thematic analysis to show the themes of Focus Group Discussion (FGD) which are discussed by the interviewers and the respondents ${ }^{(33)}$. Then the data gained from scales will be analyzed by using descriptive statistics using statistical software such as IBM SPSS, to profile the Mindfulness, Servant Leadership, Service Climate, and CO-OCB.

The two-step model approach will be used to test the model fit with $\mathrm{SEM}^{(34)}$. First, through factorial validity with Confirmatory Factor Analysis (CFA) to two measurements. Then validated by calculated estimation of the parameter of model measurement (structural model) with determining if the model showed the fitting to data. After that, we will test our hypotheses through a direct structural equation model (SEM) using Linear Structural Relationship (LISREL) 8.7 version.

\section{Preliminary Results And Current Work}

\section{A. Preliminary Results}

To dig up the profile of PT X's CO-OCB at the leader levels (manager and supervisor) and its staff; as this company is a railway transportation service provider in Indonesia, the authors had conducted a Focus Group Discussion (FGD) which involves its workers from different job position. They consisted of 10 staffs, 10 supervisors, and 5 managers. The Focus Group Discussion (FGD) lasted for 45 minutes. The Customer Oriented-Organizational Citizenship Behavior (CO-OCB) of PT X employees are evaluated from two themes points a view, which is: $\mathrm{CO}-\mathrm{OCB}$ with its dimensions which built up the $\mathrm{CO}-\mathrm{OCB}$ and factors which influence CO-OCB.

The result of Focus Group Discussion activity can be mentioned as follows. Theme 1 was the profile of $\mathrm{CO}-\mathrm{OCB}$ of PT X's employees. The general conclusion of theme 1 was the profile of CO-OCB of PT X's employees as follows: the employees from different job groups have so far worked based on their job description and standard operating procedures. They considered this as mandatory as they have been well-paid and have got sufficient reward. The employees tried to perform the extra role despite the higher job performance requirement to suit organization transformation.

Theme 2 was the factors that influence CO-OCB. The general conclusion of theme 2 showed that the factors which influence CO-OCB of PT X employees as follows: (1) Personal characteristic factor: most employees from different job position had the personality which can accept real fact, sincere, tried to perceive tense at work as their fate and it has to be taken for granted and faced, and as a part of PT X, the employees tried to instill pride in their mind, as it helps the customers be satisfied with the service offered by PT X; (2) Working attitude factor: the role model of the previous director with his serving attitude, which is followed by the present director, has inspired the managers and supervisors to apply serving leadership, the staffs felt the impact of the leadership style from the leaders, then gave the impact to their morale to serve the customers in their daily task; (3) Contextual factor: in the process of organizational transformation, PT $\mathrm{X}$ has changed and reformed its organization culture by applying 5 major values, those are: integrity, professionalism, safety, innovation, and excellent service. The new working culture which has been successfully applied has propelled the employees to develop their commitment to offering the best service to the customers and emphasize safety for train service users. In addition to those values, the employees perceived the service climate (policy, reward, technology, training) has been sufficient, even though they consider the existing office rooms, supporting facilities are meager and do not suffice. 
Furthermore, the authors also conducted a preliminary survey to find out the description of $\mathrm{CO}-\mathrm{OCB}$ in these three types of job level of the company, namely: staffs, supervisors, and managers. The number of subjects who participated in this preliminary survey was 54 people including 20 staffs, 20 supervisors, and 14 managers. The results of the preliminary survey show that in general, the CO-OCB for supervisors is in the "Moderate" category so it needs to be improved again to provide superior quality services for customers.

Table 1. CO-OCB Level of PT X's Employees

\begin{tabular}{ccc}
\hline Job Level & CO-OCB Level & Criteria \\
\hline Staffs & $85,2 \%$ & High \\
Supervisor & $70,8 \%$ & Moderate \\
Manager & $76,6 \%$ & Moderate \\
\hline
\end{tabular}

\section{B. Current Work}

After the preliminary study, the authors applied for ethical approval. The study has been approved by The Research Ethics Committee Universitas Padjadjaran Bandung (Ethical Approval No: 333/UN 6.KEP/EC/2018). Then the authors determined the instruments that will be used in this study. For these variables, namely: Servant Leadership, Service Climate, and Customer Oriented-Organizational Citizenship Behavior (CO-OCB); the authors used valid and reliable instruments from the previous research ${ }^{(3)}$. For mindfulness variable, the authors developed an instrument that specific to test the dispositional mindfulness for the employee based on the concept of mindfulness ${ }^{(15)}$. The processes of development "The Dispositional Mindfulness at Work" followed these processes, namely: determined the conceptual definition and operational definition of the construct, set the indicators and the items. After that the authors given the draft instrument of mindfulness to the expert panels to rate the instruments. Then continued to try out of the instruments. 107 employees of PT X had been followed the instrument try out process. The next work plans are the authors will collect the research data, analyze the research data, and create the final results, discussions, and conclusions chapter to finish the dissertation manuscript.

Table 2. Summary of try out results

\begin{tabular}{cccc}
\hline Variables & $\begin{array}{c}\text { Item-Total } \\
\text { Correlation }\end{array}$ & $\begin{array}{c}\text { Reliability } \\
\text { Coefficients }\end{array}$ & $\begin{array}{c}\text { Confirmator } \\
\text { y Factor } \\
\text { Analysis }\end{array}$ \\
\hline Mindfulness & $0,255-0,643$ & $\alpha=0,843$ & $\begin{array}{c}\text { All indicators } \\
\text { were valid, } \\
\text { and model } \\
\text { was fit } \\
(\mathrm{p}=0,93> \\
\end{array}$ \\
& & & $0,05)$ \\
Servant & $0,406-0,754$ & $\alpha=0,942$ & $\begin{array}{c}\text { All indicators } \\
\text { were valid, } \\
\text { and model }\end{array}$ \\
Leadership & & & was fit $(\mathrm{p}=1>$ \\
& & & $0,05)$
\end{tabular}

\begin{tabular}{|c|c|c|c|}
\hline $\begin{array}{l}\text { Service } \\
\text { Climate }\end{array}$ & $0,329-0,715$ & $\alpha=0,892$ & $\begin{array}{c}\text { and model } \\
\text { was fit } \\
(\mathrm{p}=0,033< \\
0.05)\end{array}$ \\
\hline $\mathrm{CO}-\mathrm{OCB}$ & $0,279-0,671$ & $\alpha=0,903$ & $\begin{array}{c}\text { All indicators } \\
\text { were valid, } \\
\text { and model } \\
\text { was fit } \\
(\mathrm{p}=0,00< \\
0,05)\end{array}$ \\
\hline
\end{tabular}

Extra role behavior of supervisors as citizens of the organization in providing customer-oriented services (CO-OCB) can be seen as output behavior that is also influenced by factors that exist in the supervisor and organizational factors as the context of the environment. Therefore, this study aims to prove the variables that influence $\mathrm{CO}-\mathrm{OCB}$ on supervisors that are sourced from the supervisor, namely: mindfulness and servant leadership, as well as variables originating from outside the supervisor, namely: the service climate. This study will be explained about the mechanism in the effect of mindfulness and servant leadership to $\mathrm{CO}-\mathrm{OCB}$ through service climate as a potential mediator.

This research is also expected to prove and build a structural model of the effect of mindfulness and servant leadership on CO-OCB through service climate as a potential mediator in the context of train transportation services provider in Indonesia. Furthermore, the model that is fit about the influence between the variables that have been determined in this study is expected to be useful for further research in the context of the quality of service behavior. The results of this study are also useful as comprehensive recommendations for the company in formulating policies related to human resource development and service system development to improve service performance for customers. The novelty of this study is the addition of contextual factors (service climate) as a mediator variable in testing the effect of mindfulness on workplace outcome (CO-OCB) and the influence of servant leadership on $\mathrm{CO}-\mathrm{OCB}$, and this study develops dispositional mindfulness instrument for Indonesian employees. All findings in this study can be useful for the development of concepts and theories of Service Psychology so that they can support the development of Industrial and Organizational Psychology.

\section{Conclusion}

So far, the authors have done the preliminary study and the instruments try out. The next work plans are collecting the research data, analyzing the research data, and creating the final results, discussions, and conclusions chapter to finish the dissertation manuscript. The results from this study will be proved and built a structural model of the effect of mindfulness and servant leadership on CO-OCB through a service climate. 


\section{REFERENCES}

[1] Sundiman D. Human Resource Management in the Enhancement Processes of Knowledge Management. Binus Bus Rev [Internet]. 2017;8(3):167-73. Available from: http://journal.binus.ac.id/index.php/BBR/article/view/3708

[2] Organ DW. Organizational Citizenship Behavior. In: International Encyclopedia of the Social \& Behavioral Sciences: Second Edition. 2015.

[3] Sulastiana M. Pengaruh Nilai-nilai Personal, Servant Leadership, dan Iklim Pelayanan terhadap Customer Oriented Organizational Citizenship Behavior (Studi pada Manajer Lini di Organisasi Bidang Pariwisata Jawa Barat). Disertasi. Bandung: Program Pascasarjana Universitas Padjadjaran; 2012.

[4] Nasurdin AM, Ahmad NH, Tan CL. Cultivating service-oriented citizenship behavior among hotel employees: the instrumental roles of training and compensation. Serv Bus. 2015;9(2):343-60.

[5] Organ DW, Podsakoff PM, MacKenzie SB. Organizational citizenship behavior: Its nature, antecedents, and consequences. Organizational Citizenship Behavior: Its Nature, Antecedents, and Consequences. Sage Publications; 2006.

[6] Roche M, Haar JM, Luthans F. The role of mindfulness and psychological capital on the well-being of leaders. J Occup Health Psychol. 2014;19(4):476.

[7] Sutcliffe KM, Vogus TJ, Dane E. Mindfulness in Organizations: A Cross-Level Review. SSRN. 2016.

[8] Good DJ, Lyddy CJ, Glomb TM, Bono JE, Brown KW, Duffy MK, et al. Contemplating Mindfulness at Work: An Integrative Review. J Manage. 2016;42(1):114-42.

[9] Reb J, Narayanan J, Ho ZW. Mindfulness at Work: Antecedents and Consequences of Employee Awareness and Absent-mindedness. Mindfulness (N Y). 2013;6(1):111-22.

[10] Allred C. Mindfulness and organizational citizenship behaviors: Recognizing when to help others in the workplace. East Carolina University; 2012.

[11] Reb M, Atkins PW. Mindfulness in organizations: Foundations, research, and applications. Mindfulness in Organizations: Foundations, Research, and Applications. 2015.

[12] Trong Tuan L. Knowledge Sharing in Public Organizations: The Roles of Servant Leadership and Organizational Citizenship Behavior. Int J Public Adm. 2017;40(4):361-73.

[13] Schultz PP, Ryan RM, Niemiec CP, Legate N, Williams GC. Mindfulness, Work Climate, and Psychological Need Satisfaction in Employee Well-being. Mindfulness (N Y). 2015;6(5):971-85.

[14] Kabat-Zinn J. Wherever you go, there you are: Mindfulness meditation in everyday life. Behaviour Research and Therapy. 1994

[15] Bishop SR, Lau M, Shapiro S, Carlson L, Anderson ND, Carmody J, et al. Mindfulness: A proposed operational definition. Clin Psychol Sci Pract. 2004;

[16] 1Hülsheger UR, Walkowiak A, Thommes MS. How can mindfulness be promoted? Workload and recovery experiences as antecedents of daily fluctuations in mindfulness. J Occup Organ Psychol. 2018;91(2).

[17] Greenleaf R. The power of servant-leadership. Leadership. San Fransisco: Barrett-Koehler Publisher, Inc; 1998

[18] van Dierendonck D, Nuijten I. The Servant Leadership Survey: Development and Validation of a Multidimensional Measure. Journal of Business and Psychology. 2011.

[19] Harwiki W. The Impact of Servant Leadership on Organization Culture, Organizational Commitment, Organizational Citizenship Behaviour (OCB) and Employee Performance in Women Cooperatives. In: Procedia - Social and Behavioral Sciences. 2016. p. 283-90.

[20] Liden RC, Wayne SJ, Zhao H, Henderson D. Servant leadership Development of a multidimensional measure and multi-level assessment. Leadersh Q. 2008;19(2):161-77.

[21] Newman A, Schwarz G, Cooper B, Sendjaya S. How Servant Leadership Influences Organizational Citizenship Behavior: The Roles of LMX, Empowerment, and Proactive Personality. J Bus Ethics. 2017;145(1):49-62.

[22] Nursanti TD, Anissa AD. Pengaruh Dukungan Supervisor Dan Pemberdayaan Terhadap Organizational Citizenship Behavior. Binus Bus Rev. 2014;5(1):158-65.

[23] Bande B, Fernández-Ferrín P, Varela-Neira C, Otero-Neira C. Exploring the relationship among servant leadership, intrinsic motivation and performance in an industrial sales setting. $\mathrm{J}$ Bus Ind Mark. 2016;31(2):219-31.

[24] Schneider B, White SS, Paul MC. Linking service climate and customer perceptions of service quality: Test of a causal model. J Appl Psychol. 1998;83(2):150

[25] Schneider B. Welcome to the world of services management. Acad Manag Exec. 2011;18(2):144-50.
[26] Bowen DE, Schneider B. A Service Climate Synthesis and Future Research Agenda. J Serv Res. 2014;17(1):5-22.

[27] Walumbwa FO, Hartnell CA, Oke A. Servant Leadership, Procedural Justice Climate, Service Climate, Employee Attitudes, and Organizational Citizenship Behavior: A Cross-Level Investigation. J Appl Psychol. 2010;95(3):517-29.

[28] Huang J, Li W, Qiu C, Yim FH kit, Wan J. The impact of CEO servant leadership on firm performance in the hospitality industry. Int J Contemp Hosp Manag. 2016;28(5):945-68.

[29] Chen WJ. The model of service-oriented organizational citizenship behavior among international tourist hotels. J Hosp Tour Manag [Internet]. 2016;29:24-32. Available from: http://dx.doi.org/10.1016/j.jhtm.2016.05.002

[30] Wu P-H, Liao J-F. Service-Oriented Organizational Citizenship Behavior, Perceived Service Quality and Customer Satisfaction in Hospitality Industry. In: Journal of Applied Sciences. 2016. p. 18-24.

[31] Creswell JW. Research Design: Pendekatan Kualitatif, Kuantitatif, dan Campuran. Alih bahasa oleh Achmad Fawaid dan Rianayati Kusmini Pancasari. Yogyakarta: Pustaka Pelajar; 2017.

[32] Spears LC. Character and Servant Leadership: Ten Characteristics of Effective, Caring Leaders. J Virtues Leadersh. 2010;1(1):25-30.

[33] Maguire M, Delahunt B. Doing a Thematic Analysis: A Practical, Step-by-Step Guide for Learning and Teaching Scholars. All Irel J Teach Learn High Educ. 2017;9(3):3351-33514.

[34] Kline R. Assumptions in structural equation modelling. In: Handbook of Structural Equation Modeling. New York: US: The Guilford Press; 2012. p. 111-25.

\section{AUTHORS PROFILE}

I am Dhevy Puswiartika, and affiliated in Doctoral Program of Psychology, Faculty of Psychology, Universitas Padjadjaran. My area of interest is climate change. For further details contant me at dhevy16001@mail.unpad.com

My name is Zahrotur Rusyda Hinduan, my affiliation is in Doctoral Program of Psychology, Faculty of Psychology, Universitas Padjadjaran, My area of interest is climate and change.

I am Marina Sulastiana, my qualification is Doctoral Program of Psychology, and my current affiliation is Faculty of Psychology, Universitas Padjadjaran. My area od interest is learning and enhancing the learning ability.

My name is Diana Harding, my current affiliation is Doctoral Program of Psychology, Faculty of Psychology, Universitas Padjadjaran. My area of interest is environmental learning ability. 